\section{Potentiation of the Human GABA Receptor As a Novel Mode of Action of Lower-Chlorinated Non-Dioxin-Like PCBs ${ }^{\dagger}$}

\author{
ELSA C. ANTUNES FERNANDES, *, \\ HESTER S. HEN D RIKS, \\ REGINA G. D. M. VAN KLEEF, \\ MARTIN VAN DEN BERG, AND \\ REM C O H. S . W E S T ER I N K \\ Neurotoxicology Research Group, Toxicology Division, \\ Institute for Risk Assessment Sciences, Utrecht University, \\ P.O. Box 80.177, NL-3508 TD Utrecht, The Netherlands
}

Received July 31, 2009. Revised manuscript received November 4, 2009. Accepted November 6, 2009.

PCBs are still ubiquitous pollutants despite the ban on their industrial and commercial use. To date, risk characterization and assessment of non-dioxin-like PCBs (NDL-PCBs), especially with respect to neurotoxicity, is hampered by a lack of data. Therefore, the effects of six common NDL congeners (PCB28, 52, $101,138,153$ and 180) on human $\mathrm{GABA}_{\mathrm{A}}$ receptors, expressed in Xenopus oocytes, were investigated using the twoelectrode voltage-clamp technique. When coapplied with GABA (at $\mathrm{EC}_{20}$ ), PCB28 and PCB52 concentration-dependently potentiate the $\mathrm{GABA}_{A}$ receptor-mediated ion current. Though the LOEC for both PCB28 and PCB52 is $0.3 \mu \mathrm{M}$, PCB28 is more potent than PCB52 (maximum potentiation at $10 \mu \mathrm{M}$ amounting to $98.3 \pm 12.5 \%$ and $25.5 \pm 1.4 \%$, respectively). Importantly, coapplication of PCB28 $(0.3 \mu \mathrm{M})$ and PCB52 $(10 \mu \mathrm{M})$ resulted in an apparently additive potentiation of the $\mathrm{GABA}_{A}$ response, whereas coapplication of PCB28 $(0.3 \mu \mathrm{M})$ and PCB153 (10 $\mu \mathrm{M})$ attenuated the PCB28-induced potentiation. The present results suggest that the potentiation of human $\mathrm{GABA}_{\mathrm{A}}$ receptor function is specific for lower-chlorinated NDL-PCBs and that higher molecular weight $P C B s$ may attenuate this potentiation as a result of competitive binding to human $\mathrm{GABA}_{\mathrm{A}}$ receptors. Nonetheless, this novel mode of action could (partly) underlie the previously recognized NDL-PCB-induced neurobehavioral alterations.

\section{Introduction}

Polychlorinated biphenyls (PCBs) have been widely used in numerous industrial and commercial applications (1). Although industrial production and use of PCBs has been largely prohibited in most countries since the 1980s, they are still present in electronics, plastics, and building materials. Industrial and household waste disposal remains the major source of PCBs in the environment and (2) food chain (3). Food intake is one of the main routes for human PCB exposure (4), though skin contact and inhalation also provide signifi-

* Corresponding author tel: +31-30-253 5217; fax: +31-30-253 5077; e-mail: E.C.AntunesFernandes@uu.nl.

${ }^{\dagger}$ Part of the special section "Sources, Exposures, and Toxicities of PCBs in Humans and the Environment".

₹ These authors contributed equally to this study. cant exposure due to leakage of PCBs from building material into the (indoor) environment $(5,6)$. Regardless of the route of exposure, levels of individual PCBs in human blood have been shown to be in the low $\mathrm{nM}$ range $(7,8)$.

Based on their structural characteristics and toxicological effects, PCBs can be divided into two groups: 12 coplanar dioxin-like (DL-) PCBs and 197 nonplanar non-dioxin-like (NDL-) PCBs. The DL-PCBs have been extensively studied and their toxic and biological effects are mainly associated with binding and activation of the aryl hydrocarbon receptor (AhR) transduction pathway. In contrast to the NDL-PCBs, they have been assigned a toxic equivalent factor (9) relating their toxicity to 2,3,7,8-tetrachlorodibenzo-p-dioxin (TCDD) (10). The NDL-PCBs have generally been considered less toxic because of their ortho-substituted chlorines, which impair interaction with the AhR (3).

Nevertheless, in vivo and in vitro studies have shown that NDL-PCBs have neurotoxic potential by interfering with intracellular signaling and disruption of $\mathrm{Ca}^{2+}$ homeostasis (for review see ref 11). Additionally, NDL-PCBs have been shown to inhibit the uptake of dopamine, serotonin, glutamate, and GABA in synaptosomes and synaptic vesicles isolated from rat brain $(12,13)$, and to alter neurotransmitter receptor and neurotransmitter levels in rat and mouse brain $(14,15)$. These alterations can possibly underlie the observed neurobehavioral effects in vivo, which include changes in motor activity, learning, memory, and attention (15-19). There is a strong association of these behavioral changes with the glutamatergic and dopaminergic neurotransmitter system and especially with the GABA-ergic system as GABA is the main inhibitory neurotransmitter in the adult mammalian central nervous system and provides the main inhibitory feedback for both learning and memory and motor activity (for review see ref 20). Though previous research indicated the involvement of different neurotransmitter systems, e.g., the cholinergic and GABA-ergic system in PCBmediated neurotoxicity $(15,21,22)$, acute, direct effects of PCBs on the functioning of specific neurotransmitter receptors, including dopamine, glutamate, and GABA receptors, have not been described to date.

Activation of (postsynaptic) human $\mathrm{GABA}_{\mathrm{A}}$ receptors allows for influx of $\mathrm{Cl}^{-}$resulting in hyperpolarization and a decreased activity of the neuron. GABA binds to the pentameric $\mathrm{GABA}_{\mathrm{A}}$ receptor via two GABA-binding sites. There are, however, several other binding sites that are capable of modulating $\mathrm{GABA}_{\mathrm{A}}$ receptor function. Depending on the binding site involved, the GABA-induced $\mathrm{Cl}^{-}$current can be potentiated or inhibited. Due to their physiological properties (anxiolytic, anticonvulsant, analgesic, sedative, etc.), benzodiazepine, ethanol, and neurosteroids are among the most investigated ligands (for review see ref 23 ). In vitro and in vivo studies have shown that the prolonged use of, e.g., anesthetics or anxiolytic drugs can eventually lead to cell apoptosis in rat brain by disruption of the $\mathrm{GABA}_{\mathrm{A}}$ receptor function (9).

In 2005, the European Food and Safety Authority (EFSA) released a risk assessment publication regarding the presence of NDL-PCBs in feed and food. In this report, six abundant NDL-congeners (PCB28, 52, 101, 138, 153, and 180) were identified as representing together $\sim 50 \%$ of the total amount of NDL-PCBs in food (4). Despite the abundance of these congeners in food, these reference congeners have been used only in a limited number of in vivo and in vitro studies. Consequently, risk characterization and risk assessment of these relevant NDL-PCBs is hampered by a lack of data. Moreover, as specific effects 
of these NDL-PCBs on neurotransmitter receptors function have not been described, the aim of the present study was to investigate whether the above-mentioned six common (highly purified) NDL-PCBs can exert acute effects on the function of the predominant receptor of the main inhibitory neurotransmitter in the mammalian brain, i.e., the $\mathrm{GABA}_{\mathrm{A}}$ receptor.

\section{Experimental Section}

Animals. All experiments were conducted in accordance with Dutch law and approved by the Utrecht University Ethical Committee for Animal Experiments. Adult female specimen of Xenopus laevis frogs (provided by Dr. Wim Scheenen, Radboud University, Nijmegen, The Netherlands) were kept in copper-free water $\left(\mathrm{pH} 7,1.25 \mathrm{mmol} \mathrm{CaO} / \mathrm{L}, 24{ }^{\circ} \mathrm{C}\right)$ in standard aquaria $(0.5 \times 0.4 \times 1 \mathrm{~m} ; 1-15$ per aquarium $)$ with a $12 \mathrm{~h} \mathrm{light/dark} \mathrm{cycle.} \mathrm{The} \mathrm{animals} \mathrm{were} \mathrm{fed} \mathrm{earthworms}$ three times a week (Hagens, Nijkerkerveen, The Netherlands).

Chemicals. Gabazine, GABA, neomycin solution (10 mg neomycin $/ \mathrm{mL}$ in $0.9 \% \mathrm{NaCl}$ ), collagenase type $\mathrm{I}, \mathrm{NaCl}$ and 3-aminobenzoic acid ethyl ester (MS-222) were obtained from Sigma Chemical (St. Louis, MO). $\mathrm{CaCl}_{2}$ (1 M solution), $\mathrm{MgCl}_{2}$ (1 M solution), $\mathrm{MgSO}_{4}, \mathrm{NaHCO}_{3}, \mathrm{NaOH}, \mathrm{Ca}\left(\mathrm{NO}_{3}\right)_{2}, \mathrm{KCl}$, and HEPES were purchased from Merck (Darmstadt, Germany). cDNAs of human $\mathrm{GABA}_{\mathrm{A}}$ subunits were synthesized and provided by Paul J. Whiting (Merck Sharp \& Dohme Research Laboratories, Neuroscience Research Centre, Harlow, Essex, UK).

Highly purified (>99.2\%) PCBs were purchased from Neosync Inc., USA. The possible presence of PCDD/Fs and DL-PCBs impurities in the NDL-PCBs was removed by Stenberg and Andersson (Institute of Environmental Chemistry, Umeå University, Umeå, Sweden) by applying a fractionation on active carbon cleanup step. The six NDLPCBs used were PCB28 (2,4,4'-trichlorobiphenyl), PCB52 (2,2',5,5'-tetrachlorobiphenyl), PCB101 $\left(2,2^{\prime}, 4,5,5^{\prime}\right.$-pentachlo-

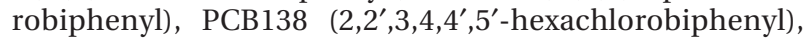
PCB153 (2,2', 4, $4^{\prime}, 5,5^{\prime}$-hexachlorobiphenyl) and PCB180 $\left(2,2^{\prime}, 3,4,4^{\prime}, 5,5^{\prime}\right.$-heptachlorobiphenyl). PCB126 (3, $3^{\prime}, 4,4^{\prime}, 5-$ pentachlorobiphenyl) was used as DL-PCBs reference congener. PCBs and gabazine were dissolved in purity-checked dimethyl sulfoxide (DMSO), provided by Stenberg and Andersson (Institute of Environmental Chemistry, Umeå University, Umeå, Sweden). PCBs stock solutions of $25 \mathrm{mM}$ were further diluted to obtain a final experimental concentration ranging from $10 \mathrm{nM}$ to $10 \mu \mathrm{M}$. Gabazine stock solution of $100 \mathrm{mM}$ was further diluted to obtain an experimental concentration of $25 \mu \mathrm{M}$. DMSO at concentrations up to $0.5 \%$ $(\mathrm{v} / \mathrm{v})$ had no effect on the $\mathrm{GABA}_{\mathrm{A}}$ receptor mediated $\mathrm{Cl}^{-}$ currents. In the present experiments, the final concentration of DMSO in PCB (and gabazine)-containing saline was always kept below $0.1 \%(\mathrm{v} / \mathrm{v})$.

Expression of $\alpha_{1} \beta_{2} \gamma_{2 L} G_{A B A}$ Receptors in Xenopus laevis Oocytes. All procedures are essentially as described previously (24). Briefly, female Xenopus laevis were anesthetized by submersion in $0.1 \%$ MS-222 and ovarian lobes were surgically removed. Oocytes were treated with collagenase type I (1.5 $\mathrm{mg} / \mathrm{mL} \mathrm{Ca}{ }^{2+}$ free Barth's solution) for $90 \mathrm{~min}$ at room temperature before manual defolliculation. cDNA coding for the human $\alpha_{1}, \beta_{2}$, and $\gamma_{2 \mathrm{~L}}$ subunits of human GABA $\mathrm{A}_{\mathrm{A}}$ receptors, dissolved in distilled water at a 1:1:1 molar ratio, was injected into the nuclei of stage V or VI oocytes using a Nanoject Automatic Oocyte Injector (Drummond, Broomall, PA). The injected volume was $23 \mathrm{~nL} /$ oocyte $(\sim 1 \mathrm{ng}$ of each subunit). Sham-injected oocytes were injected only with $23 \mathrm{~nL}$ of distilled-water, i.e., without cDNA. Oocytes from Xenopus laevis are a commonly used tool in studying direct effects plasma membrane proteins (receptors) (for review see ref 25). The foreign cDNA of the receptor of choice, injected into the nucleus of the oocyte, is translated and the expected functional receptor is subsequently expressed in the membrane of the oocyte. Consequently, this system is very suitable to study direct effects of drugs and chemicals on neurotransmitter receptor function (24). Following injection of the cDNA, or only demi-water, oocytes were incubated at 21 ${ }^{\circ} \mathrm{C}$ in modified Barth's solution containing (in $\mathrm{mM}$ ) $88 \mathrm{NaCl}$, $1 \mathrm{KCl}, 2.4 \mathrm{NaHCO}_{3}, 0.3 \mathrm{Ca}\left(\mathrm{NO}_{3}\right)_{2}, 0.41 \mathrm{CaCl}_{2}, 0.82 \mathrm{MgSO}_{4}, 15$ HEPES, and $10 \mu \mathrm{g} / \mathrm{mL}$ neomycin ( $\mathrm{pH} 7.6$ with $\mathrm{NaOH}$ ). Experiments were performed on oocytes after 2-5 days of incubation. Each experiment was repeated on oocytes obtained from two or three different animals.

Electrophysiological Recording. Following translation of injected cDNA the oocytes expressed functional GABA receptors in the membrane. Ion currents associated with $\mathrm{GABA}_{\mathrm{A}}$ receptor activity were measured with two-electrode voltage clamp techniques using a Gene Clamp 500B amplifier (Axon Instruments) with high-voltage output stage according to the methods described previously (24). Recording microelectrodes (0.5-2.5 M 2 ) were filled with $3 \mathrm{M} \mathrm{KCl}$. Oocytes, placed in a Teflon recording tube, were voltage clamped at $-60 \mathrm{mV}$ and continuously superfused $(\sim 30 \mathrm{~mL} / \mathrm{min}$ ) with saline solution, containing (in $\mathrm{mM}$ ): $115 \mathrm{NaCl}, 2.5 \mathrm{KCl}, 1 \mathrm{CaCl}_{2}, 10$ HEPES (pH 7.2 with $\mathrm{NaOH}$ ). Aliquots of freshly thawed stock solutions of GABA in demiwater and of the different PCBs and gabazine in DMSO were added to the saline immediately before the experiments. Oocytes were exposed to compounds by switching the perfusate from saline to PCB and/or GABA-containing saline using a servomotor-operated valve. For specific experiments, oocytes were exposed to a mixture of PCBs $(0.3 \mu \mathrm{M}$ PCB28 $+10 \mu \mathrm{M}$ PCB52 or $0.3 \mu \mathrm{M}$ PCB28 $+10 \mu \mathrm{M}$ PCB153) or a mixture of PCB28 $(10 \mu \mathrm{M})$ and gabazine (25 $\mu \mathrm{M})$. To minimize absorption of PCBs to the perfusion system, glass reservoirs and Teflon tubes (PTFE; $4 \times 6$ $\mathrm{mm}$, Rubber, Hilversum, The Netherlands) were used. Ocytes were exposed repeatedly to different GABA- and/ or PCB-containing solutions. Therefore, a washout period of 2-5 min between each application was introduced, allowing receptors to recover from desensitization. The lipophilic nature of the PCBs apparently did not affect the observed rapidly reversible potentiation of the GABAevoked response, as repeated applications of PCBs did not enhance or attenuate the effect. Membrane currents were low-pass filtered (8-pole Bessel; $3 \mathrm{~dB}$ at $0.3 \mathrm{kHz}$ ), digitized (12 bits; 1024 samples/record), and stored on disk for computer analysis.

Data Analysis and Statistics. Peak amplitudes of GABAinduced ion currents were measured and normalized to the amplitude of GABA-induced ( $1 \mathrm{mM}$ ) control responses to adjust for differences in receptor expression levels among oocytes and for small variations in response amplitude over time. Normalized ion currents were plotted against GABA concentration in each experiment. A GABA concentration-effect curve was fitted to the data obtained in separate experiments using Prism (Graphpad Software, La Jolla, CA). The percentage of PCB-induced potentiation of the GABA-induced ion current was calculated from the quotient of the maximum amplitude of the GABA-PCB coapplication response (during $20 \mathrm{~s}$ ) and the maximum amplitude of the control response. Data represent mean \pm SEM of $n$ oocytes.

The concentration-dependence of the potentiating effects of PCBs were determined by one-way ANOVA $(p<0.05)$ and posthoc Bonferroni testing. A two-tailed unpaired Student's $t$-test $(p<0.05)$ was used to determine the effects of binary PCB mixtures.

\section{Results}

Functional Properties of Human GABA $_{\mathbf{A}}$ Receptors Expressed in Xenopus laevis Oocytes. Oocytes expressing 


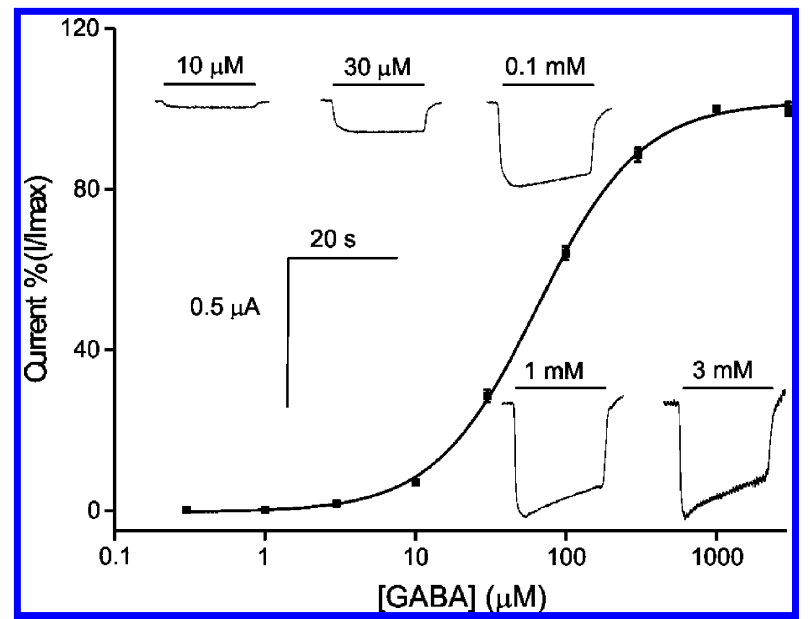

FIGURE 1. GABA concentration-response curve of human $\alpha_{1} \beta_{2} \gamma_{2 L} G A B A_{A}$ receptors expressed in Xenopus oocytes. The fitted line is a Hill curve with a slope of 1.27 and an EC $_{50}$ of $65 \mu$ M. Data are mean \pm SEM $(n=10)$. Insets show example recordings of inward $\mathrm{Cl}^{-}$currents evoked at different GABA concentrations, as indicated by the solid lines on top of the recordings.

human $\alpha_{1} \beta_{2} \gamma_{2 \mathrm{~L}} \mathrm{GABA}_{\mathrm{A}}$ receptors, voltage-clamped at $-60 \mathrm{mV}$, were exposed to saline solution containing $0.3 \mu \mathrm{M}$ to $3 \mathrm{mM}$ of GABA. Ion current amplitude increased with increasing GABA concentration and saturated around $1 \mathrm{mM} \mathrm{GABA}$ (see insets Figure 1). Normalized GABA-induced currents were plotted against GABA concentration to obtain a concentration-effect curve and to determine $\mathrm{EC}_{20}, \mathrm{EC}_{50}$, and $\mathrm{EC}_{80}$ values, i.e., the concentrations producing $20 \%, 50 \%$, and $80 \%$ of the maximal response (Figure 1). In line with previous reports $(26,27)$, the concentration-effect curve was best fitted with a Hill coefficient of $1.27( \pm 0.05)$, and $\mathrm{EC}_{20}, \mathrm{EC}_{50}$, and $\mathrm{EC}_{80}$ values amounted to 22,65 , and $193 \mu \mathrm{M}(n=10)$, respectively.

NDL-PCBs Effects on GABA $_{\mathbf{A}}$ Receptor Activation. In subsequent experiments, six common NDL-PCBs (PCB28, $52,101,138,153$ and 180) and one DL-PCB (PCB126) were screened for possible antagonistic and agonistic effects on $\mathrm{GABA}_{\mathrm{A}}$ receptor activation. To assess possible agonistic effects on the human $\mathrm{GABA}_{\mathrm{A}}$ receptors, oocytes were exposed to PCB-containing saline (1 or $10 \mu \mathrm{M}$ ) for $20 \mathrm{~s}$. However, at these concentrations none of the tested PCBs was able to activate $\mathrm{GABA}_{\mathrm{A}}$ receptors (not shown).

Further, coapplication of these PCBs $(1 \mu \mathrm{M}$ and $10 \mu \mathrm{M})$ with $\mathrm{GABA}$ either at $\mathrm{EC}_{20}$ or at $\mathrm{EC}_{80}$ revealed that none of these PCBs had antagonistic properties (not shown). However, upon coapplication of $\mathrm{GABA}_{\text {at }} \mathrm{EC}_{20}$, but not $\mathrm{EC}_{80}$, with PCB28 or PCB52 a marked potentiation of the GABA-induced ion current was observed (Figure 2A). This potentiation appeared to be specific for lower-chlorinated NDL-PCBs as PCB101, 126, 138, 153, and 180 were unable to potentiate the GABA-induced ion current (Figure 2A). The potentiation of the GABA-induced ion current (at $\mathrm{EC}_{20}$ ) by PCB28 and PCB52 was further tested at concentrations ranging from $10 \mathrm{nM}$ to $10 \mu \mathrm{M}$. The PCB-induced potentiation was concentrationdependent (ANOVA, $p<0.05$; Figure 2B), with a lowest observed effect concentration (LOEC) of $0.3 \mu \mathrm{M}$ for both PCBs. The maximum concentration of PCBs used was $10 \mu \mathrm{M}$ as the solubility of PCBs is limited and higher concentrations lack toxicological relevance. Consequently, it was impossible to determine complete concentration-response curves and to calculate the corresponding $\mathrm{EC}_{50}$ s. Although both PCBs have the same LOEC for potentiation of the $\mathrm{GABA}_{\mathrm{A}}$ receptor, at higher concentrations ( $>1 \mu \mathrm{M})$ PCB28 is more potent than PCB52 (Figure 2B). At the highest concentration tested (10 $\mu \mathrm{M})$, the potentiation of the GABA-induced ion current by
PCB28 and PCB52 amounted to $98.2 \pm 12.5 \%(n=7)$ and $24.5 \pm 1.4 \%(n=8)$, respectively. To exclude the possibility that NDL-PCBs exert their potentiating effects via another, natively expressed, receptor, sham-injected oocytes (lacking $\mathrm{GABA}_{\mathrm{A}}$ receptors) were exposed to the NDL-PCBs that were able to potentiate the $\mathrm{GABA}_{\mathrm{A}}$ receptor. None of the tested NDL-PCBs showed any effect (data not shown) in these shaminjected oocytes. Additionally, pharmacologically blocking the GABA-binding site of the $\mathrm{GABA}_{\mathrm{A}}$ receptor using gabazine (25 $\mu \mathrm{M})$, completely abolished the GABA/NDL-PCB effect (not shown), underlining that the NDL-PCB effect is a direct, $\mathrm{GABA}_{\mathrm{A}}$ receptor-mediated effect. These findings thus indicate that PCB28 and PCB52 act as partial agonists of the $\mathrm{GABA}_{\mathrm{A}}$ receptor in vitro.

Effects of Binary Mixtures of NDL-PCBs on GABA $_{A}$ Receptor Activation. PCB28 and PCB52 both potentiate the GABA-evoked ion current. However, human exposure is generally not to individual PCB congeners, but to mixtures of different PCBs, which could result in additive effects. Therefore, oocytes were coexposed to GABA (at EC 20 ) and an approximately equipotent mixture of PCB28 and PCB52. As shown in Figure $3 \mathrm{~A}$, coapplication of GABA (at $\mathrm{EC}_{20}$ ) with only PCB28 $(0.3 \mu \mathrm{M})$ or only PCB52 $(10 \mu \mathrm{M})$ induced a potentiation of the GABA-evoked ion current of $15.0 \pm 2.3 \%$ and $25.5 \pm 1.4 \%$, respectively. Coapplication of GABA (at $\left.\mathrm{EC}_{20}\right)$ with a mixture of PCB28 $(0.3 \mu \mathrm{M})$ and PCB52 $(10 \mu \mathrm{M})$ evoked a significantly larger potentiation $(43.5 \pm 7.7 \%$; $p<$ 0.05 ) of the GABA-evoked current, demonstrating that under these conditions the potentiating effects of PCB28 and PCB52 are likely additive.

PCB153, which has neurotoxic potency $(17,28)$, is among the most abundant PCBs found in the environment as well as human and animal samples (7). However, PCB153 (up to $10 \mu \mathrm{M})$ was not able to potentiate the GABA-evoked ion current. When oocytes were exposed to GABA (at $\mathrm{EC}_{20}$ ) with a mixture of PCB28 $(0.3 \mu \mathrm{M})$ and PCB153 $(10 \mu \mathrm{M})$, the PCB28evoked potentiation of the GABA-evoked current was significantly attenuated from $15.0 \pm 2.3 \%$ to $1.6 \pm 0.9 \%$ (Figure $3 \mathrm{~B} ; p<0.05)$. These combined results indicate that the composition of the mixture apparently determines whether additive potentiation (mixture of lower-chlorinated NDLPCBs) or competitive binding/antagonism (mixture of lowerchlorinated and higher molecular weight NDL-PCBs) occurs.

\section{Discussion}

The present results demonstrate a novel mode of action for NDL-PCBs. Lower-chlorinated NDL-PCBs, i.e., PCB28 and PCB52, act as a partial agonist on the human $\mathrm{GABA}_{\mathrm{A}}$ receptor, whereas the other tested, higher-molecular weight NDL-PCBs are unable to activate the receptor (Figure 2A). Potentiation of the GABA-evoked response by PCB28 and PCB52 apparently depends on the level of receptor occupancy as it occurs when GABA is applied at $\mathrm{EC}_{20}$, but not at $\mathrm{EC}_{80}$. Further, the lack of effect of the NDL-PCBs on sham-injected oocytes and the abolishment of the GABA and NDL-PCBs effect by the specific $G_{A B A}$ receptor antagonist gabazine clearly shows that the NDL-PCB-induced potentiation is a direct, $\mathrm{GABA}_{\mathrm{A}}$ receptor-mediated effect. Importantly, in our in vitro system, the effects of PCB28 $(0.3 \mu \mathrm{M})$ and PCB52 $(10 \mu \mathrm{M})$ on $\mathrm{GABA}_{\mathrm{A}}$ receptor potentiation are apparently additive (Figure $3 \mathrm{~A})$, whereas coapplication of PCB28 $(0.3 \mu \mathrm{M})$ and PCB153 (10 $\mu \mathrm{M})$ attenuated this potentiation (Figure $3 \mathrm{~B}$ ), suggesting antagonism or competitive binding.

A wide range of toxic properties of PCBs has been described earlier, including adverse effects on the endocrine system, especially effects of PCBs on the AhR and thyroid hormone signaling (for review see refs 10, 29-31). Though several of these endocrine effects are specifically linked to DL-PCBs, a large number of studies reported neurotoxic 


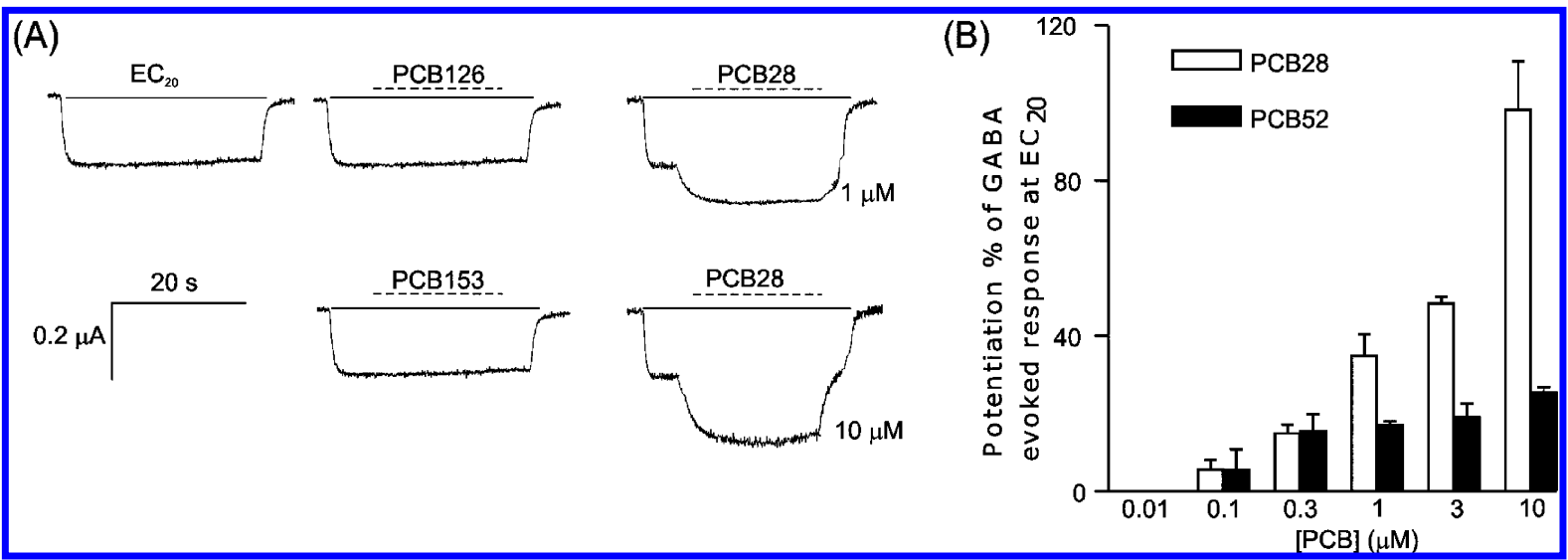

FIGURE 2. Potentiation by PCB28 and PCB52 of GABA-evoked ion currents under conditions of low receptor occupancy. (A) Example recordings of $\mathrm{Cl}^{-}$current evoked by $\mathrm{GABA}$ at $\mathrm{EC}_{20}$ (indicated by the solid line on top of the recording, upper left). During the application of GABA (at $\mathrm{EC}_{20}$ ), PCBs were coapplied for 20 s (dashed line on top of the recordings). Penta-chlorinated PCBs, like the dioxin-like PCB126 or higher-chlorinated NDL-PCBs, do not affect the GABA-evoked ion current (middle traces). The lower-chlorinated NDL-PCB28 induces a dose-dependent potentiation of the GABA-evoked ion current (right traces). Scale bar applies to all traces. (B) Bar graph demonstrating the concentration-dependent potentiation of GABA-induced responses by PCB28 and PCB52. LOECs, i.e., the lowest PCB concentrations that significantly potentiate the GABA-evoked ion current, amounted to $0.3 \mu \mathrm{M}$ for both PCBs. Bars represent mean \pm SEM $(n=3-22)$.
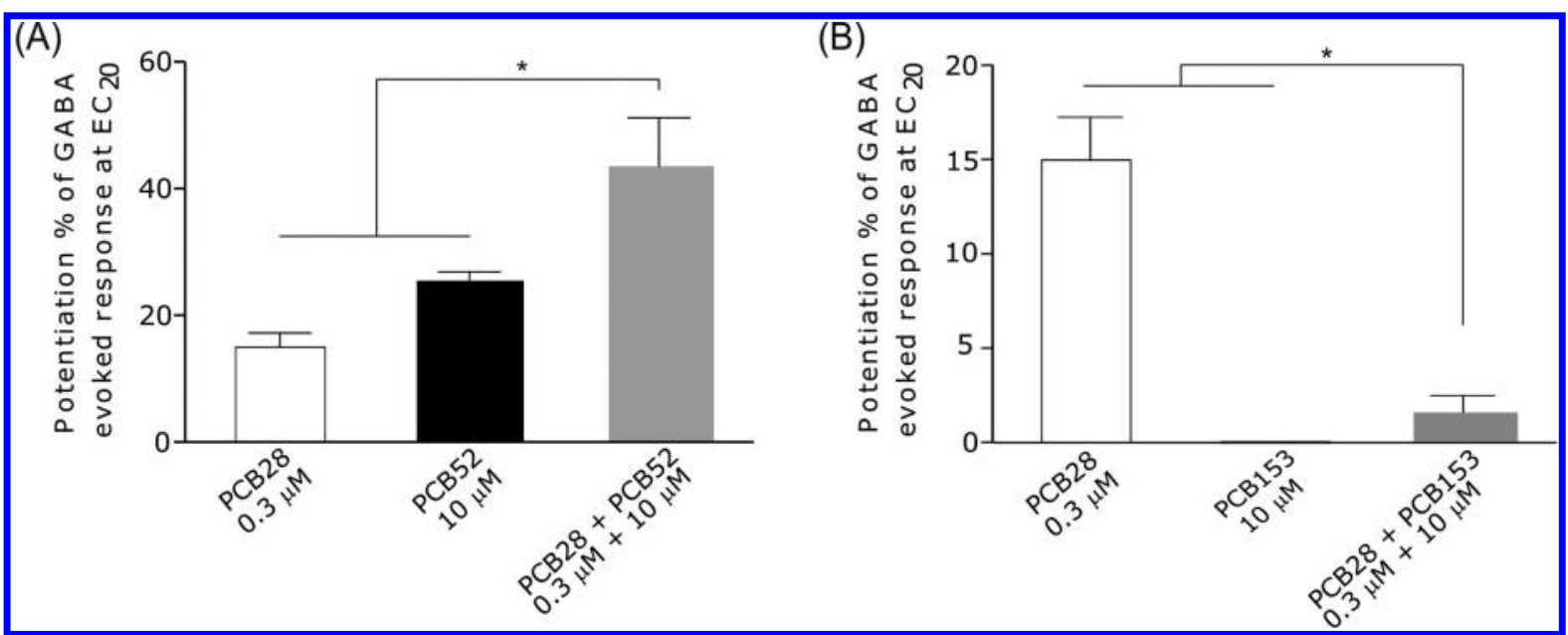

FIGURE 3. Bar graph demonstrating the potentiation of GABA-induced ion current by PCB28 (0.3 $\mu \mathrm{M})$, PCB52 (10 $\mu \mathrm{M})$, PCB153 (10 $\mu \mathrm{M})$, and PCB mixtures. (A) PCB28 $(0.3 \mu \mathrm{M})$ and PCB52 $(10 \mu \mathrm{M})$ both potentiate the GABA-evoked ion current (potentiation amounts to $15.0 \pm 2.3 \%$ and $25.5 \pm 1.4 \%$, respectively). Coapplication of GABA at EC $_{20}$ with a mixture of PCB28 and PCB52 potentiated the GABA-evoked ion current, apparently in an additive manner, to $43.5 \pm 7.7 \%\left({ }^{*}, p<0.05\right.$ compared either of the PCBs alone). (B) PCB153 $(10 \mu \mathrm{M})$ was not able to potentiate the GABA-evoked ion current. Coapplication of GABA at EC 20 with a mixture of PCB28 $(0.3 \mu \mathrm{M})$ and PCB153 $(10 \mu \mathrm{M})$ potentiated the GABA-induced ion current $(1.6 \pm 0.9 \%)$, but the potentiation was strongly attenuated compared to the potentiation of PCB28 alone $\left(15.0 \pm 2.3 \%\right.$; $\left.{ }^{*}, p<0.05\right)$. Data are mean \pm SEM $(n=7-12)$.

effects, which are mainly associated with exposure to NDLPCBs. Exposure, especially developmental exposure, to NDLPCBs has been reported to induce neurobehavioral and neurological effects, e.g., mild impairment of learning and memory and motor activity (15). Several cellular effects have been described that could underlie these subtle effects, including altered brain neurotransmitter levels due to changes in neurotransmitter synthesis, metabolism, and transporters. Moreover, NDL-PCBs have been reported to induce oxidative stress and increase the intracellular $\mathrm{Ca}^{2+}$ concentration (for review see refs 11, 32, 33).

As PCBs comprise a large number of congeners, previous studies addressed the neurotoxic potential of PCBs according to their chlorination pattern. Inhibition of vesicular neurotransmitter uptake has been shown to be specific for orthosubstituted PCBs, with penta- and hexa-chlorinated PCBs being the most potent (12). Similarly, inhibition of membrane transporter-mediated neurotransmitter uptake is also specifically inhibited by ortho-substituted PCBs, with tetra- and penta-chlorinated PCBs showing the strongest inhibition (13).
Further, PCB-induced ryanodine receptor activation (34), Protein Kinase C (PKC) translocation (35-37), and decrease in cell dopamine content (38) appeared again specific for ortho-substituted PCBs, with penta-chlorinated congeners, especially PCB153, being among the most potent PCBs. Disruption of $\mathrm{Ca}^{2+}$ homeostasis has been identified as one of the major neurotoxic effects of NDL-PCBs (39-41), with penta- and hexa-chlorinated congeners among the most effective PCBs (41).

All these cellular effects are, however, related to presynaptic neurotransmission or cytotoxicity, whereas acute, postsynaptic effects have not been described. Further, our data suggest that the potentiation of the GABA-induced ion currents by NDL-PCBs is exclusive for lower-chlorinated congeners, namely PCB28 and PCB52, whereas higherchlorinated and dioxin-like PCB126 were unable to potentiate the $\mathrm{GABA}_{\mathrm{A}}$ receptor (Figure $2 \mathrm{~A}$ ). However, additional studies are required to further investigate this suggested Structure Activity Relation (SAR) and the suggested additive effect of lower-chlorinated PCBs on the $\mathrm{GABA}_{\mathrm{A}}$ receptor. 
Human exposure to NDL-PCBs is not restricted to a single congener and in our in vitro system the effects of the binary mixture of PCB28 and PCB52 on the $\mathrm{GABA}_{\mathrm{A}}$ receptor activation indicate that these congeners likely interact in an additive way. This property has been described before suggesting that NDL-PCBs can act via the same specific site when perturbing $\mathrm{Ca}^{2+}$ homeostasis and causing PKC translocation (37). However, the present experiments with a binary mixture of PCB28 and PCB153 have shown that the potentiating effect of PCB28 is reduced by the higher-chlorinated congener (Figure $3 \mathrm{~B}$ ), suggesting antagonism or competitive binding to the $\mathrm{GABA}_{\mathrm{A}}$ receptor. This receptor has several binding sites via which PCBs can exert their effects. PCB153 may exert competitive binding to the $\mathrm{GABA}_{\mathrm{A}}$ receptor if it binds to the same binding site as PCB28, though without activating it. Alternatively, PCB28 and PCB153 may also bind to different sites on the same receptor, but with the binding of PCB153 hampering the binding of PCB28, e.g., by shielding the binding site via which PCB28 potentiates the $\mathrm{GABA}_{\mathrm{A}}$ response. PCB28 and PCB52 potentiate the GABA-evoked response at $\mathrm{EC}_{20}$, but not at $\mathrm{EC} 80$ or in the absence of GABA and this GABA/NDL-PCB effect is abolished by the specific GABA antagonist gabazine. Further, none of the tested PCB congeners was able to inhibit the GABA-evoked ion current. The results thus suggest that lower-chlorinated NDL-PCBs act via one of the potentiating allosteric binding sites, but not via one of the two GABA binding sites or any of the antagonistic binding sites of the $\mathrm{GABA}_{\mathrm{A}}$ receptor, e.g., the picrotoxin binding site (20). However more experiments are required to confirm this.

Due to their lower molecular weight, lower-chlorinated PCBs are among the most abundant congeners in indoor air and dust samples in both public and private buildings, due to leakage from PCB-containing ceilings and other construction materials. Especially for children and toddlers, inhalation and dust ingestion are major routes of exposure to (lowerchlorinated) PCBs (42). Human plasma levels of individual lower-chlorinated PCBs, including PCB28 and PCB52, amount on average to $0.03 \mathrm{nM}$ following exposure via contaminated indoor air (43). The LOECs for PCB28 and PCB52 in our study are in the low $\mu \mathrm{M}$ range $(0.3 \mu \mathrm{M})$. Despite the nearly four orders of magnitude difference between these LOECs and human serum concentration, the reported effects could be relevant if additivity applies, as humans and wildlife are generally exposed to a mixture of NDL-PCBs. Higherchlorinated PCBs, including PCB153, are among the most abundant congeners found in food and feed, therefore food ingestion is one of the most important routes of exposure to these particular congeners. For the three most abundant NDL-PCBs (PCB138, 153, and 180), blood levels as high as $50 \mathrm{nM}$ have been reported for people living in a contaminated area in Eastern Slovakia (7), which lowers the margin of safety substantially. However, it should be noted that these higherchlorinated persistent NDL-PCBs are unable to potentiate the $\mathrm{GABA}_{\mathrm{A}}$ receptor. On the contrary, $\mathrm{PCB} 153$ can decrease the potentiating effect of PCB28, indicating that the composition of the NDL-PCBs mixture (and the relative concentration of the different congeners) will determine the net effect on the $\mathrm{GABA}_{\mathrm{A}}$ receptor.

The six common NDL-PCBs used in this study account for approximately $50 \%$ of all the NDL-PCBs present in feed and food. Therefore, the novel mode of action observed in the present experiments should be taken into account for human risk assessment of NDL-PCBs. Additionally, these results also indicate that a thorough exposure characterization for lower-chlorinated NDL-PCBs, and especially their (toxicological) contribution within a relevant mixture, is one of the prerequisites for human risk assessment for these PCBs.

\section{Acknowledgments}

Authors E.C.A.F. and H.S.H. contributed equally to this study. We gratefully acknowledge Ing. Aart de Groot (Neurotoxicology Research Group, IRAS) for excellent technical assistance, Dr. Patrik Andersson and Mia Stenberg (Institute of Environmental Chemistry, Umeå University, Umeå, Sweden) for purification of the PCBs, Dr. Paul J. Whiting (Merck Sharp \& Dohme Research Laboratories, Neuroscience Research Centre, Harlow, Essex, UK) for providing the cDNA encoding the human $\mathrm{GABA}_{\mathrm{A}}$ subunits, and Dr. Wim Scheenen (Radboud University, Nijmegen, The Netherlands) for providing the Xenopus leavis frogs. This work was funded by the European Union (FOOD-CT-2005-022923).

\section{Literature Cited}

(1) Safe, S. Toxicology, structure-function relationship, and human and environmental health impacts of polychlorinated biphenyls: progress and problems. Environ. Health Perspect. 1993, 100, 259-68.

(2) Neisel, F.; von Manikowsky, S.; Schumann, M.; Feindt, W.; Hoppe, H. W.; Melchiors, U. [Human biomonitoring of polychlorinated biphenyls in 130 exposed elementary school children]. Gesundheitswesen 1999, 61 (3), 137-49.

(3) Toxicological Profile for Polychlorinated Biphenyls (PCBs); Agency for Toxic Substances \& Disease Registry: Atlanta, GA, 2000.

(4) Opinion of the Scientific Panel on Contaminants in the Food Chain on a Request from the Commission Related to the Presence of Non-Dioxin-Like Polychlorinated Biphenyls (PCB) in Feed and Food; European Food Safety Authority, 2005.

(5) Broding, H. C.; Schettgen, T.; Goen, T.; Angerer, J.; Drexler, H. Development and verification of a toxicokinetic model of polychlorinated biphenyl elimination in persons working in a contaminated building. Chemosphere 2007, 68 (8), 1427-34.

(6) Peper, M.; Klett, M.; Morgenstern, R. Neuropsychological effects of chronic low-dose exposure to polychlorinated biphenyls (PCBs): a cross-sectional study. Environ. Health 2005, 4, 22.

(7) Petrik, J.; Drobna, B.; Pavuk, M.; Jursa, S.; Wimmerova, S.; Chovancova, J. Serum PCBs and organochlorine pesticides in Slovakia: age, gender, and residence as determinants of organochlorine concentrations. Chemosphere 2006, 65 (3), 410-8.

(8) Gabrio, T.; Piechotowski, I.; Wallenhorst, T.; Klett, M.; Cott, L.; Friebel, P.; Link, B.; Schwenk, M. PCB-blood levels in teachers, working in PCB-contaminated schools. Chemosphere 2000, 40 $(9-11), 1055-62$.

(9) Ikonomidou, C.; Bittigau, P.; Ishimaru, M. J.; Wozniak, D. F.; Koch, C.; Genz, K.; Price, M. T.; Stefovska, V.; Horster, F.; Tenkova, T.; Dikranian, K.; Olney, J. W. Ethanol-induced apoptotic neurodegeneration and fetal alcohol syndrome. Science 2000, 287 (5455), 1056-60.

(10) Van den Berg, M.; Birnbaum, L. S.; Denison, M.; De Vito, M.; Farland, W.; Feeley, M.; Fiedler, H.; Hakansson, H.; Hanberg, A.; Haws, L.; Rose, M.; Safe, S.; Schrenk, D.; Tohyama, C.; Tritscher, A.; Tuomisto, J.; Tysklind, M.; Walker, N.; Peterson, R. E. The 2005 World Health Organization reevaluation of human and Mammalian toxic equivalency factors for dioxins and dioxinlike compounds. Toxicol. Sci. 2006, 93 (2), 223-41.

(11) Tilson, H.A.; Kodavanti, P. R. Neurochemical effects of polychlorinated biphenyls: an overview and identification of research needs. Neuro Toxicol. 1997, 18 (3), 727-43.

(12) Mariussen, E.; Andersson, P. L.; Tysklind, M.; Fonnum, F. Effect of polychlorinated biphenyls on the uptake of dopamine into rat brain synaptic vesicles: a structure-activity study. Toxicol. Appl. Pharmacol. 2001, 175 (2), 176-83.

(13) Mariussen, E.; Fonnum, F. The effect of polychlorinated biphenyls on the high affinity uptake of the neurotransmitters, dopamine, serotonin, glutamate and GABA, into rat brain synaptosomes. Toxicology 2001, 159 (1-2), 11-21.

(14) Seegal, R. F.; Brosch, K. O.; Okoniewski, R. J. Effects of in utero and lactational exposure of the laboratory rat to $2,4,2^{\prime}, 4^{\prime}-$ and $3,4,3^{\prime}, 4^{\prime}$-tetrachlorobiphenyl on dopamine function. Toxicol. Appl. Pharmacol. 1997, 146 (1), 95-103.

(15) Eriksson, P.; Fredriksson, A. Developmental neurotoxicity of four ortho-substituted polychlorinated biphenyls in the neonatal mouse. Environ. Toxicol. Pharmacol. 1996, 1 (3), 155-165.

(16) Piedrafita, B.; Erceg, S.; Cauli, O.; Monfort, P.; Felipo, V. Developmental exposure to polychlorinated biphenyls PCB153 or PCB126 impairs learning ability in young but not in adult rats. Eur. J. Neurosci. 2008, 27 (1), 177-82. 
(17) Eriksson, P.; Fischer, C.; Fredriksson, A. Polybrominated diphenyl ethers, a group of brominated flame retardants, can interact with polychlorinated biphenyls in enhancing developmental neurobehavioral defects. Toxicol. Sci. 2006, 94 (2), 302-9.

(18) Schantz, S. L. Developmental neurotoxicity of PCBs in humans: what do we know and where do we go from here? Neurotoxicol. Teratol. 1996, 18 (3), 217-27; discussion 229-76.

(19) Holene, E.; Nafstad, I.; Skaare, J. U.; Sagvolden, T. Behavioural hyperactivity in rats following postnatal exposure to sub-toxic doses of polychlorinated biphenyl congeners 153 and 126. Behav. Brain Res. 1998, 94 (1), 213-24.

(20) Mohler, H. Molecular regulation of cognitive functions and developmental plasticity: impact of GABAA receptors. I. Neurochem. 2007, 102 (1), 1-12.

(21) Inglefield, J. R.; Shafer, T. J. Perturbation by the PCB mixture aroclor 1254 of GABA(A) receptor mediated calcium and chloride responses during maturation in vitro of rat neocortical cells. Toxicol. Appl. Pharmacol. 2000, 164 (2), 184-95.

(22) Kim, K. H.; Inan, S. Y.; Berman, R. F.; Pessah, I. N. Excitatory and inhibitory synaptic transmission is differentially influenced by two ortho-substituted polychlorinated biphenyls in the hippocampal slice preparation. Toxicol. Appl. Pharmacol. 2009, 237 (2), 168-77.

(23) D'Hulst, C.; Atack, J. R.; Kooy, R. F. The complexity of the GABAA receptor shapes unique pharmacological profiles. Drug Discov. Today 2009, 14 (17-18), 866-75.

(24) Zwart, R.; Vijverberg, H. P. Potentiation and inhibition of neuronal nicotinic receptors by atropine: competitive and noncompetitive effects. Mol. Pharmacol. 1997, 52 (5), 886-95.

(25) Sigel, E.; Minier, F. The Xenopus oocyte: system for the study of functional expression and modulation of proteins. Mol. Nutr. Food Res. 2005, 49 (3), 228-34.

(26) Huang, S. H.; Duke, R. K.; Chebib, M.; Sasaki, K.; Wada, K.; Johnston, G. A. Bilobalide, a sesquiterpene trilactone from Ginkgo biloba, is an antagonist at recombinant alphalbeta2gamma2L GABA(A) receptors. Eur. J. Pharmacol. 2003, 464 (1), $1-8$.

(27) Scheller, M.; Forman, S. A. The gamma subunit determines whether anesthetic-induced leftward shift is altered by a mutation at alpha1S270 in alphalbeta2gamma2L GABA(A) receptors. Anesthesiology 2001, 95 (1), 123-31.

(28) Fischer, C.; Fredriksson, A.; Eriksson, P. Neonatal co-exposure to low doses of an ortho-PCB (PCB 153) and methyl mercury exacerbate defective developmental neurobehavior in mice. Toxicology 2008, 244 (2-3), 157-65.

(29) Langer, P. Persistent organochlorinated pollutants (PCB, DDE, HCB, dioxins, furans) and the thyroid--review 2008. Endocr. Regul. 2008, 42 (2-3), 79-104.

(30) Darras, V. M. Endocrine disrupting polyhalogenated organic pollutants interfere with thyroid hormone signalling in the developing brain. Cerebellum 2008, 7 (1), 26-37.

(31) Zoeller, T. R.; Dowling, A. L.; Herzig, C. T.; Iannacone, E. A.; Gauger, K. J.; Bansal, R. Thyroid hormone, brain development, and the environment. Environ. Health Perspect. 2002, 355-61; 110 Suppl 3: p.

(32) Faroon, O.; Jones, D.; de Rosa, C. Effects of polychlorinated biphenyls on the nervous system. Toxicol. Ind. Health 2001, 16 (7-8), 305-33.

(33) Mariussen, E.; Fonnum, F. Neurochemical targets and behavioral effects of organohalogen compounds: an update. Crit. Rev. Toxicol. 2006, 36 (3), 253-89.

(34) Wong, P. W.; Brackney, W. R.; Pessah, I. N. Ortho-substituted polychlorinated biphenyls alter microsomal calcium transport by direct interaction with ryanodine receptors of mammalian brain. J. Biol. Chem. 1997, 272 (24), 15145-53.

(35) Kodavanti, P. R.; Ward, T. R.; McKinney, J. D.; Tilson, H. A. Increased $[3 \mathrm{H}]$ phorbol ester binding in rat cerebellar granule cells by polychlorinated biphenyl mixtures and congeners: structure-activity relationships. Toxicol. Appl. Pharmacol. 1995, 130 (1), 140-8.

(36) Svendsgaard, D. J.; Ward, T. R.; Tilson, H. A.; Kodavanti, P. R. Empirical modeling of an in vitro activity of polychlorinated biphenyl congeners and mixtures. Environ. Health Perspect. 1997, 105 (10), 1106-15.

(37) Kodavanti, P.R.; Ward, T. R. Interactive effects of environmentally relevant polychlorinated biphenyls and dioxins on $[3 \mathrm{H}]$ phorbol ester binding in rat cerebellar granule cells. Environ. Health Perspect. 1998, 106 (8), 479-86.

(38) Shain, W.; Bush, B.; Seegal, R. Neurotoxicity of polychlorinated biphenyls: structure-activity relationship of individual congeners. Toxicol. Appl. Pharmacol. 1991, 111 (1), 33-42.

(39) Kodavanti, P. R.; Ward, T. R.; McKinney, J. D.; Tilson, H. A. Inhibition of microsomal and mitochondrial $\mathrm{Ca} 2+$-sequestration in rat Cerebellum by polychlorinated biphenyl mixtures and congeners. Structure-activity relationships. Arch. Toxicol. 1996, 70 (3-4), 150-7.

(40) Mundy, W. R.; Shafer, T. J.; Tilson, H. A.; Kodavanti, P. R. Extracellular calcium is required for the polychlorinated biphenyl-induced increase of intracellular free calcium levels in cerebellar granule cell culture. Toxicology 1999, 136 (1), 27-39.

(41) Pessah, I. N.; Hansen, L. G.; Albertson, T. E.; Garner, C. E.; Ta, T. A.; Do, Z.; Kim, K. H.; Wong, P. W. Structure-activity relationship for noncoplanar polychlorinated biphenyl congeners toward the ryanodine receptor-Ca2+ channel complex type 1 (RyR1). Chem. Res. Toxicol. 2006, 19 (1), 92-101.

(42) Harrad, S.; Ibarra, C.; Robson, M.; Melymuk, L.; Zhang, X.; Diamond, M.; Douwes, J. Polychlorinated biphenyls in domestic dust from Canada, New Zealand, United Kingdom and United States: implications for human exposure. Chemosphere 2009, 76 (2), 232-8.

(43) Liebl, B.; Schettgen, T.; Kerscher, G.; Broding, H. C.; Otto, A.; Angerer, J.; Drexler, H. Evidence for increased internal exposure to lower chlorinated polychlorinated biphenyls (PCB) in pupils attending a contaminated school. Int. J. Hyg. Environ. Health 2004, 207 (4), 315-24.

\section{ES902321A}

